Volume and Issues Obtainable at Center for Sustainability Research and
Consultancy
Sustainable Business and Society in Emerging Economies
ISSN: 2708-2504 \& ISSN (E): 2708-2172
Volume 3: Issue 3 September 2021
CSRட
Journal homepage: www.publishing.globalcsrc.org/sbsee

\title{
Impact of Credit Risk on Financial Performance: Mediating role of Operational Efficiency in Banking Sector of Emerging Economy
}

Muhammad Husnain, Department of Business Administration, University of Sahiwal, Sahiwal, Pakistan

*Qaisar Maqbool Khan, Department of Commerce, Bahauddin Zakariya University, Multan, Pakistan

Mumtaz Ahmad, Department of Commerce, The Islamia University of Bahawalpur,Pakistan Zainab, Putra Business School, Malaysia

*Corresponding author's email: qmk707@gmail.com

\begin{tabular}{l}
\hline ARTICLE DETAIL \\
\hline History \\
Revised format: Aug 2021 \\
Available Online: Sep 2021 \\
\hline Keywords: Operational \\
Efficiency, Financial \\
Performance, Credit Risk, \\
Banking sector.
\end{tabular}

JEL Classification

C58, E51, E58, G21

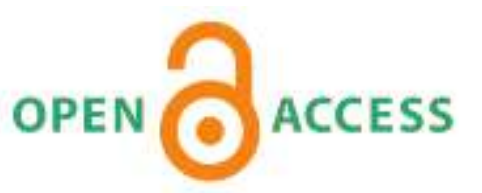

\section{ABSTRACT}

Purpose: Financial performance of banks is an estimation of how better a company can use its assets for generating profits. Mostly the performance of banks is affected by modernization of financial system, technological advancements and deregulation. The aim of this study is to examine the mediating role of operational efficiency in relationship between credit risk and financial performance of banks.

Design/Methodology/Approach: The research sample is 29 banks of Pakistan. Data for the study is collected from the published financial statements of banks ranges from 2011 to 2018. The data analysis technique used in this study is simple mediation analysis in structure equation modeling.

Findings: The results reflect that operational efficiency partially significantly and inversely mediates the relationship of credit risk with financial performance.

Implications/Originality/Value: One the basis of results it can be suggested that managers need to utilize their deposits carefully and should take more precautionary measures while granting loans. Managers and employees should maintain a better relationship and align their goals with the banks.

(C) 2021, The authors, under a Creative Commons AttributionNonCommercial 4.0

Recommended citation: Husnain, M., Khan, M. Q., Ahmad, M. and Zainab. (2021). Impact of Credit Risk on Financial Performance: Mediating role of Operational Efficiency in Banking Sector of Emerging Economy. Sustainable Business and Society in Emerging Economies, 3 (3), 253-263. 


\section{Introduction}

Bank is referred to as "a financial institution that invests the money of its clients and investors and works as a financial broker between the investors who have a surplus and the investors who borrow these money to cover their investment needs". Mostly the performance of banks is affected by modernization of financial system, technological advancements and deregulation (Tarus et al., 2012). Such factors form the shape of profitability and costs incurred by management. In every financial institution acceptable generation of revenue is the major concern also take severity of risk exposure in its consideration (Raza et al., 2019). The financial system of any economy always contributes a lot in transmitting funds from different sources into profitable investments which can increase economic growth so inequality of income can be decreased in an economy (Rao, 2016). Bank contributes a lot in the growth of an economy because banks are intermediaries between those who provides funds to banks in the form of deposits and those who needs who are in the need of funds (Asmar, 2018).

Financial Performance of banks is an estimation of how better a bank can use its assets from its private mechanism of business and generate profits. This term is used as the general estimation of an organization's overall financial strength over a given period of time (Nazmoon Akhtar, 2018). Financial performance can be used by the analysts to compare different firms and organizations in aggregate. A company has many stakeholders that consists of trade creditors, employees, bondholders and management. Each of them has their own interest in analyzing the financial performance of any organization (Harcourt, 2017). Stakeholders or analysts get information regarding financial performance of any organization from the annual reports published the company. Stakeholders use these reports for getting accurate and consistent information given in financial statements that provide an outline of a company's financial performance (Boadi et. al., 2016).

There are different determinants of financial health of banks are observed. Banks with better financial performance are essential for better economic health. Banks with better financial performance can make economy of a country more stable. Bank specific factors are those factors which can help in identify the current financial situation of banks in such poor economic situations and also to investigate are those factors are maintaining banks financial and also to address which areas of financial system of banks needs improvement. Profitability or financial performance is referred to as usage of assets by firms for the purpose of generating revenue. Both factors internal or external can have huge impact on financial performance of firm. Economic activities are facilitated by the financial intermediaries through collaboration these units and eradicating the hindrances in financial relations. Financial intermediaries are presented as delegated monitor minimizing costs of monitoring and problem of free-riding can be decreased which is increasing in public markets. Financial intermediaries are also mitigating principal agent problems.

Efficiency is referred to as "the best allocation of resources to obtain the highest level of output it measures a bank's performance in relation to a set standard for a specified period of time" (Ray and Rammohan, 2004). We can say bank efficiency means how banks can minimize expenses or cost and with that maximize their profits with operating current level of production. Banks need to take into consideration input and output facet for enhancing the performance of efficiency. Their main focus is on reduction of cost as well on the expansion of revenue. There are some concepts of efficiency which include for the purpose of making analysis of bank performance which includes revenue efficiency, cost efficiency and profit efficiency (Mahendru and Bhatia, 2014). 
There are different researches done on the relationship between different internal and external factors of banks and operational efficiency and profitability (Ahmad \& Matemilola, 2019; Olarewaju \& Obalade, 2015; Eldomiaty, 2015; Muskowa, 2014). According to the study of Olarewaju \& Obalade, 2015 Loan to deposit ratio has a negative influence on operational efficiency. According to them if bank gives more amount to public as loan then is always chance of more default. According to the study of Eldomiaty, (2015) conducted in Egypt credit risk and capital ratio has a positive and significant with operating efficiency. The positive relationship between credit risk and operational efficiency reflects banks in Egypt undergo increasing expenses related to interest to the degree that banks depend on increasing total loans.

The objective of this study is to find the impact of credit risk on financial performance with mediating role of operational efficiency in banking sector of emerging economy. It is known that geographical location of Pakistan is quite strategic this has increased the regional integration and globalization maximized the importance of banking of Pakistan on the globe (Hafez, 2018). Financial performance of banks of Pakistan are becoming more better day by day but still Pakistani banks are facing problems for maintaining their profitability and needs for more better policy implications for management (Raza et al., 2019). Therefore, several studies have been conducted to examine the factors affecting financial performance of banks such as bank size, credit risk, loan to deposit ratio, deposit ratio, asset utilization and operational efficiency (Ahmad \& Matemilola, 2019; Olarewaju \& Obalade, 2015; Eldomiaty, 2015; Muskowa, 2014). There are some other studies done on several factors like firm size influencing financial performance with mediating role of operational efficiency (Prybudi et al, 2017; Ruslan et al, 2019). Therefore, this study analyze whether operational efficiency plays a mediating role in the relationship between credit risk and financial performance in emerging economy of Pakistan. Data is acquired from all the 29 banks that were operational in Pakistan from the year 2013 to 2018. The study uses net interest margin (total interest income - total interest expense/total asset) as a proxy for financial performance. To identify the mediation in relationship between independent and dependent variables study apply single level mediation model. This study extends the previous researches by adding more factors in Pakistan banking sector. This study will help in assessing whether operational efficiency is intervening factor for determining financial performance in terms on net interest margin.

\section{Literature Review}

Credit Risk is one of the most essential determinants which influence profitability of banking because lending is one of the basic functions of bank and there are many chances that a borrower may default at the time of recovery (Ikram et. al., 2016). BASEL defines credit risk as "potential that a borrower or counter party will fail to meet its obligations in accordance with agreed terms." The central reason of credit risk is that the time limit of borrowed amount is not honored by debtors as mentioned in the contract. In this risk debtors cannot fulfil their financial obligation as it is agreed (Hu, 2012).

Credit risk occurs where the correspondents are in the condition of fulfil their commitment. According to Base II loans are the biggest and noticeable cause of credit risk for majority the banks (Sharifi et. al., 2019). Credit risk refers to as a probability that borrower will be unable to fulfil his or her obligations according to the specified terms and conditions. Managing risk of credit grants banks to customize this order by relocating the loans from their own records to a third-party servicer (Lassoued, 2017). By permitting credit a bank can generate large amount of interest income and it also indicates financial performance of any bank. In some cases, loans can't perform as expected and appear as bad debts and have a poor impact on financial performance of banks 
(Ferhi, 2017). If we talk about the issues faced by financial institutions especially banks the central reason of severe banking problems is strongly related to underprivileged risk management. Sometimes banks expand their credit with the assumption that borrowers are able to pay the amount borrowed and as a consequence bank's earnings started to decrease because of the arrangement of the amount that recover the loss occur due to default in loan repayments of borrowers (Poudel, 2018). Credit Risk has the ability to generate enormous risk-taking and eradicate majority of the bank's equity that results in bankruptcy and management of credit risk creates new challenges for banking sector. Financial institutions that involve in lending to consumers and businesses can take risks and face large losses in case of default in payments. Many creditors assess the life of growth (Al-Shakrchy, 2017).

Handling the exchange between risk and return continual profitability in banking sector. Credit risk one of the most essential risk which has a strong relationship asset which provoke substantial income (Ferhi, 2017). Management of credit risk is essential because it builds better credit portfolio and it is of supreme importance for booming financial performance of banks and other and financial institutions and also the whole economy (Sharifi et. al., 2019). In the literatures of finance and economics, deficiency can be seen in management of credit risk results in crisis of banking sector which has adverse impact on economy. Credit risk management is the critical indicator of financial performance. Thus, the prosperity of financial performance of banks relies on the efficacy of management of credit risk (Gizaw et.al 2018).

Banks now a days give more consideration to credit risks. The reason is that providing loans is a dominant mechanism by which banks make profits so more consideration is given to credit risk (Ikram et. al., 2016). The robustness of banks in an economy is estimated by how banks efficiently manage its credit risks. Credit risks are systemically linked with financial performance. Whenever banks provide loans to borrowers every loan has its own risk (Lassoued, 2017). An analytical assessment regarding the trends of banking in the past gave us indication that risks related to asset portfolio became the reason of most of banks to worry about (Basel committee on banking supervision, 2006). The capability of a bank for earnings and to continue its operations rely on how efficiently it responds to risks and to able eliminate the effects of non-performing loans. There are different risks and they are managed differently but one thing is same among them and credit risk which is the requirement of identification of risk and to plan for the weakening the effects of risks (Kutum, 2017). The process of risk protection includes banks take necessary measures before providing loans and revamping decrepit credit facilities. In past, banks analyze the borrowers by checking the background of borrowers and their credit history and then a time comes when banks secured loans through taking their valuable belongings as securities so in case of default banks possession of their belongings (Yimka et. al., 2015). Now a days banks check the borrower's ability to generate profit from the cash borrowed. Borrower's ability is analyzed through an efficient appraisal system of credit by dissecting the applications of loans before advancing of loans to reduce credit risk (Kutum, 2017).

The primary reasons of credit risk include narrow capacity of institutions, irrelevant policies of credit, erratic rates of interest, poor interest rates, low levels of capital and liquidity etc (Sun \& Chang, 2018). To curtail the risks, it is crucial that any financial structure should have banks with maximum capital that can protect banks from insolvency, banks should provide its service to broad range of customers, interest rates should be stabilize, non-performing loans should be minimized, deposits should be increased and increased credit should be extended to borrowers. Default in loans and non-performing loans should be reduced (Basel committee on banking supervision, 2006). Management policies of credit are applied by different banks according to their ownership 
like private, government and foreign banks, policies of credit, credit calculating systems, banks regulatory setting and the competence of management of banks (Gizaw et.al 2018). Sometimes banks have adequate management polices of credit but still not document high revenues. In addition, sometimes industry set standards regarding which credit policy is better and which policy is unsuitable and in addition banks have different attributes (Yimka et.al, 2015).

Credit Risk is also called the default risk. It is most crucial type of risk exposed by many financial organizations especially banks. It is the probability of loss which can be arise when the borrower defaults in payment of loans according to agreed terms (Al-shakrchy, 2017). Management of credit risk provides a fair and well-designed approach for the identification, estimation and risk prioritization for the purpose taking action in order to reduce the chance of risks. An efficient management of risk preparation doesn't eradicate risk but curtail risk (Akram \& Rahman, 2018). If effective credit risk management is implemented and maintained then an organization can increase the efficiency of its business processes (Nwude \& Okeke, 2018). There are a lot of advantages of this efficient risk management such as it can the assets, time and personnel of the organization and also protects the image and position of the company, bank can also shun fines for not confirming to the regulations of central bank and for the building the capability for tackling with the uncertain situations and it can also heighten competitive advantage with the help of better decision making and market understanding which is based on authentic modified credit risk management instruction and it can also increase value of shareholder and it also enhance their confidence (ferhi, 2017).

Credit is given more importance because banks now-a-days are facing greater level of anticipated risks from the attributes of its clients and their business situations. Management of credit risk is crucial to every business especially for banks because the main inventory of bank is cash (Rajhi \& Hassairi, 2014). The main activity from which banks earn profit is lending and the basic purpose of lending is risk reduction, which is to figure out the capability of borrower and the tendency to repay the amount that is borrowed (Saravia Matus, 2015). Management of credit risk begins with gauging the probability of credit risk which involves borrower's past records regarding his borrowings with other banks or financial institutions and his or her earnings (Antwi \& Apau, 2015). A borrower with better credit rating mien less risk rather than borrower with poor rating. It can't be possible to isolate the banking system from credit risk management and this process should extended and should also be implemented wherever banking system exists (Musah et al., 2018). For the implementation of efficient credit risk management depends upon financial managers that they should have deep understanding of risks that corporate may face in future and how those managers link such risks with credit risk. Such type of understanding helps in identification, measurement, monitoring and controlling of credit risk so that the necessary steps should be taken to minimize risk (Nwadu and Okeke, 2018).

The principles of credit risk management are implemented for the purpose of value creation and for tackling uncertain situation depend upon on the information which is available. Providing credit is the central source of earning of a commercial bank and it is also the reason of credit risk (Mukoswa, 2014). The credit risk management also impacts on banks profitability as well. Actually, finite size of a financial institution, improper policies of credit, fluctuating rates of interest, indulgence in assessment of credit, underprivileged lending practices, imprudent system of collateral, intervention by governments and poor supervision by central banks included by credit risk (Poudel, 2018). When credit risk of bank increases than chances insolvency also increases. Greater exposure of credit risk leads to the greater financial crisis of financial institutions especially banks. The framework of credit risk is very critical for the sustainability of both private 
and government banks (ferhi, 2017). Lending or advancing loans to borrowers have a risk of default but banks also extend their services to those borrowers who have good credit history and bank is sure of that he or she will pay the loan (Sun \& Chang, 2018).

Efficiency is referred to as "the possibility of firms to produce a certain level of certain optimal level of output from a given bundle of inputs or a certain level of output at minimum cost" (Farrell and Amaza, 2005). Efficiency can be an important component for the production growth in such economy which is facing shortage of resources and lack opportunities for advance technologies. Some studies showed that productivity can be increased without escalating the resource base or enhancing technology by improvement of efficiency (Adeyemi, 2017). Operational efficiency means assessment of bank's relative performance by lowering operating expenses or costs so it can produce the output which is similar to technological condition. Revenue efficient banks are those banks which estimates the performance comparatively with banks of best practice with production of maximum output and minimum input. A firm or bank can achieve this efficiency by choosing a combination of input and output through which a firm or bank earn maximum revenue at the applicable prices of input and output.

According a study of Mukoswa, 2014 credit risk negatively influenced operational efficiency of banks but according to his studies with low market share can't be able to manage risks regarding advancing loans. His study also high lights that there are structural differences high market and low market share banks. And further also explained decrease operational efficiency also decrease financial performance of banks. So according to the above discussion we can say may be credit has a significant effect on financial performance of banks through operational efficiency of banks. So, we can develop the following hypothesis:

Ho: There is no significant impact of credit risk on financial performance of banks via operational efficiency.

$\mathbf{H}_{1}$ : There is a significant impact of credit risk on financial performance of banks via operational efficiency.

\section{Data and Research Methodology}

Pakistani banking sector encompasses private banks, government banks, microfinance banks, specialized banks and foreign bank. There are 34 banks operating in Pakistan according to Pakistan stock exchange. But in this research, we select 29 banks for our study. The rest of the banks are excluded because of improper data. For our purpose of study, the other 5 banks are excluded from the study due lack of financial data that is needed for the study. Data is acquired from all the 29 banks that were operational in Pakistan from the year 2013 to 2018. Secondary data is collected from the financial annual reports from the website of state bank of Pakistan and World Bank website for period 2013-2018. Financial reports represent information on income statement for the year for the banks and also the balance sheet information as the year ends and notes of other accounts.

\section{Measurement of Variables}

This section discusses the measurement of the studied variables.

\section{Net Interest Margin}

Net Interest Margin reflects the capacity of earning by employing all assets through core business of banking. Banks normally get cash in form of deposits from savers and lend this 
money to the investors. It is estimated through difference between interest earned by the bank and interest expense divided by total assets (Asmar, 2018). Interest rate margins are the most essential factor that gauge the financial performance of banks and sometimes wide interest margins have a positive effect and sometimes they have a negative effect on financial institutions. We measure the bank performance with the following formula:

Net Interest Margin= Interest Income - Interest Expense/Total Assets

\section{Credit Risk}

It is estimated by non-performing loans divided by total loans. It reflects the proportion of loans that have been finally written off from the cash book. The figure of this ratio should be lower because in comparable banks this written off policy is the same. Credit risk is an essential internal or micro economic factor that effects the efficiency of banks. Management of risk is a vibrant aspect which is strongly related to its operating activities and a bank's survival, any variation in credit risk demonstrates the health of loan portfolio of the banks. Poor quality of assets increases probability of failure of banks (Cooper et al., 2003). Previous literature reflects that risk-taking of banks can be dependent on operational efficiency. Banking business is one of the riskiest businesses because each activity of bank is not separated from risk. The primary function of bank work as an intermediary between depositors and borrowers the most prominent risk faced by banks is credit risk (Raharjo et al., 2014). The scale used for measuring operational efficiency is taken from the study of (Bargam and Ali, 2018) as follows:

Credit Risk= non-performing loans/Total loans

\section{Operational Efficiency}

It refers to "how bank is being efficient in terms of utilizing its resources to achieve maximum output" (Gilbert et al, 2008). Operational efficiency is estimated by dividing interest income, non-interest income and security gains by interest expense, non-interest expense and provisions of loan losses and taxes (eldomiaty et al, 2015). The scale used for measuring operational efficiency is taken from the study of (Bargam \& Ali, 2018) as follows:

Operational Efficiency= Interest income + non-interest income + securities gains/Interest + non-interest expense + provisions for loan losses + taxes

\section{Empirical Findings}

This table 1 reflects Pakistani banks overall performance regarding internal determinants effecting financial performance from 2011 to 2018. The mean value of net interest margin is .0410 with a minimum ratio of -.0014 and with maximum ratio of .161 , while the mean value of the operational efficiency is .0380 with minimum value of 0007 and maximum ratio of .308. Similarly, the descriptive stat of the credit risk is also presented in table 1.

Table 1

Descriptive Statistics

\begin{tabular}{lcccc}
\hline Variable & Mean & Std. Dev. & Min & Max \\
\hline Credit Risk & 0.104 & 0.0968 & 0 & 0.79
\end{tabular}


Operational Efficiency

Net Interest Margin
0.038

0.041
0.036

0.0007

0.308

\section{Impact of Credit Risk on Net Interest Margin via Operational Efficiency}

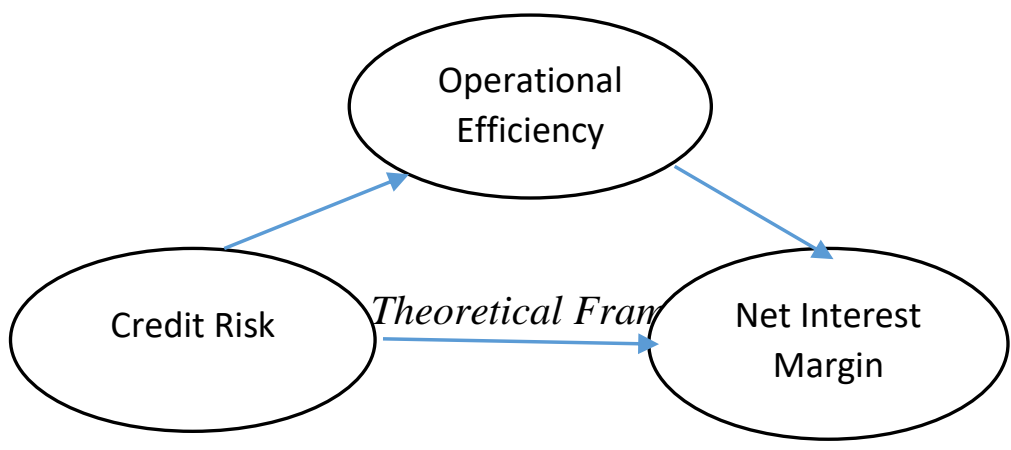

In this table we observe that the direct effect of operational efficiency on net interest margin is positive which shows that operational efficiency has a direct and significant impact on net interest margin $(\beta=.676$ at $p<0.05)$. On the other hand, credit risk has a direct negative and significant effect on net interest margin $(\beta=-.1063174$ at $p<0.05)$. While indirectly but negatively effects the net interest margin via operational efficiency $(\beta=-.1321$ at $p<0.05)$. In total effects we observe that credit risk has a significant but negative impact on operational efficiency $(\beta=-.2384$ at $p<0.05)$ and operational efficiency has a positive and significant impact on net interest margin $(\beta=$ .6763384 at $p<0.05$ ) and credit risk has significant and negative impact on operational efficiency. According to Hayes, A. F. (2017) if both direct and indirect effect are significant then that is partial mediation and our results are reflecting operational efficiency partially mediating the relationship between credit risk and net interest margin.

Table 2

Direct Effect
Coefficient
P-Value

\begin{tabular}{lll} 
Operational Efficiency & & \\
Credit Risk & -0.1953 & 0 \\
Net Interest Margin & & \\
Operational Efficiency & 0.6763 & 0 \\
Credit Risk & -0.1063 & 0 \\
\hline
\end{tabular}

Table 3

Indirect Effect

\begin{tabular}{ll}
\hline Coefficient & P-Value \\
\hline
\end{tabular}

Net Interest Margin 
Operational Efficiency

Credit Risk

$-0.1321$

0

Table 4

Total Effect

\begin{tabular}{cccc}
\hline & Coefficient & P-Value \\
\hline Operational Efficiency & & \\
Credit Risk & -0.1953 & 0 \\
\hline Net Interest Margin & & \\
Operational Efficiency & 0.67634 & 0 \\
Credit Risk & -0.2384 & 0 \\
\hline
\end{tabular}

According to results in the tables credit risk has negative and significant impact on net interest margin. In direct affects table, it can be observed credit risk has negatively and significantly affecting net interest margin. The result is in the agreement with arguments of Kwan, (1997), Saunders et al., (1990) and Mukoswa, (2014). According to authors management and shareholders have agency problems in banks.In banks managers have risk taking attitude and they take more risks for the purpose of their own benefits. Such managers letting down the objectives of banks shareholder and this can increase problems between management and shareholders. The reason is managers try to achieve more loan target keeping in mind their benefits this in result increase nonperforming loans. This can also decrease financial performance/net interest margin and same can be observed in table of indirect affects that operational efficiency is significantly mediating relation between credit risk and net interest margin. The result is consistent with Mukoswa, (2014). According to author increase in non-performing increase operating costs which cause decrease in net interest margin.

In table no. 5 goodness of fit is presented which guide whether the model is suitable for study or not. According to the study of Daire Hooper, et al. 2008 if root mean square error of approximation is below 0.08 that means the model is fit. Baseline comparison contains comparative fit index and Tucker-Lewis index both of which values should be minimum 0.90 and maximum above 0.90. Both values in the model are above 0.90 which means the model is fit. Another value namely Standard root mean squared residual also studied and this value should be below 0.08 and our result indicate that its value is below 0.08 that means our model is fit.

Table 5

Model fit indices

\begin{tabular}{ccc}
\hline Fit Statistic & Value \\
\hline Population error & & \\
RMSEA & & \\
lower bound & 0.000 & RMSE of approximation \\
upper bound & 0.00 & \\
& 0.00 & \\
& $1.000 \quad$ Comparative fit index \\
CFI & $1.000 \quad$ Tucker-Lewis index \\
TLI & & \\
Size of residuals & 0.000 & Standardized RMS residual \\
SRMR & & \\
\hline
\end{tabular}




\section{Conclusion of study}

This study examines the impact of credit risk on the financial performance of banks with mediating role of operational efficiency. This study used credit risk as independent variables, operational efficiency as mediating variables and net interest margin as dependent variable and proxy for financial performance. For sample selection this study used 29 banks based on availability of data. The time horizon of this study is 8 years started from 2011 to 2018 on annual basis. To identify the mediation in relationship between independent and dependent variables study apply single level mediation model.

The negative relationship found between credit risk and net interest margin via operational efficiency. Credit risk also have negative impact on operational efficiency which means higher credit inversely impact net interest margins of banks via operational efficiency. It is caused by higher distribution of loans by managers for their own benefits and this cause problems between shareholders and managers which cause increase in non-performing loans and thus decreasing net interest margin. Therefore, according to this managers should maintain a good relationship with shareholders and other supervisory authorities and higher authorities. Shareholders should also plan some incentives for managers for the purpose of increasing their commitment towards the bank and monitoring regarding providing loans needs to be improved. This way, the nonperforming loans can be decreased which in turn increase efficiency thus in financial performance/net interest margin of banks.

This study can help managers to make policies regarding granting loans to protect banks from loan defaults and make policies regarding reward system for employees so they can align their goals with the banks and avoid agency problems and help managers make policy regarding better utilization of deposits. The limitations of this study are that 29 banks are chosen out of total banks in Pakistan because of improper information and limitations of this study is that this research only limited to banks and few factors were used, time period in this is not so much long and only Pakistan banks is used in this study. The future research can be done other sectors of the country and other countries can be added in this research and time period can be extended.

\section{References}

Aguenaou, S., Lahrech, A., \& Bounakaya, S. (2017). Analyzing banks' efficiency as a measurement of performance in the Moroccan context: Application of CAMEL Framework. International Review of Research in Emerging Markets and the Global Economy (IRREM), 3(1), 1105-1121.

Alam, J., \& Akhter, N. (2019). An assessment of Bank-Specific factors on operational efficiency: An empirical study on selected commercial banks in Bangladesh.

Al-Harbi, A. (2019). The determinants of conventional banks profitability in developing and underdeveloped OIC countries. Journal of Economics, Finance and Administrative Science.

Al-Homaidi, E. A., Tabash, M. I., Farhan, N. H., \& Almaqtari, F. A. (2018). Bank-specific and macro-economic determinants of profitability of Indian commercial banks: A panel data approach. Cogent Economics \& Finance, 6(1), 1548072.

Boadi, E. K., Yao, L., \& Lartey, V. C. (2016). Role of Bank Specific, Macroeconomic and Risk Determinants of Banks Profitability: Empirical Evidence from Ghana's Rural Banking Industry. International journal of economics and financial Issues, 6(2).

Bustaman, Y., Ekaputra, I. A., Husodo, Z. A., \& Prijadi, R. (2017). Impact of interest margin, market power and diversification strategy on banking stability: Evidence from ASEAN4. AJBA, 10(1), 1-44. 
Chernobai, A. S., Rachev, S. T., \& Fabozzi, F. J. (2008). Operational risk: a guide to Basel II capital requirements, models, and analysis (Vol. 180). John Wiley \& Sons.

Egbunike, C. F., \& Okerekeoti, C. U. (2018). Macroeconomic factors, firm characteristics and financial performance. Asian Journal of Accounting Research.

Eldomiaty, T., Fikri, A., Mostafa, W., \& Amer, H. H. (2015). The financial determinants of operating efficiency for Lowand High Competitive Banks in Egypt. Journal of Finance and Bank Management, 3(2), 7-23.

Hadhek, Z., Frifita, M., \& Hamida, A. (2018). The determinants of Cost Efficiency of Islamic Banks using SFA Approach. International Research Journal of Finance and Economics, 168, 33-47.

Hamadi, H., \& Awdeh, A. (2012). The determinants of bank net interest margin: Evidence from the Lebanese banking sector. journal of Money, Investment and banking, 23(3), 85-98.

Harcourt, E. (2017). Credit risk management and performance of deposit money banks in Nigeria. International Journal of Managerial Studies and Research, 5(8), 47-57.

Islam, M. S., \& Nishiyama, S. I. (2016). The determinants of bank net interest margins: A panel evidence from South Asian countries. Research in International Business and Finance, 37, 501-514.

Kawshala, H., \& Panditharathna, K. (2017). The factors effecting on bank profitability. International Journal of Scientific and Research Publications, 7(2), 212-216.

Khan, F., Anuar, M. A., Choo, L. G., \& Khan, H. (2011). Determinants of bank profitability in Pakistan: A case study of Pakistani banking sector. World Applied Sciences Journal, 15(10), 1484-1493.

Leykun, F. (2016). Factors affecting the net interest margin of commercial bank of Ethiopia. International Journal of Scientific and Research Publications, 6(6), 150-161.

Lotto, J. (2019). Evaluation of factors influencing bank operating efficiency in Tanzanian banking sector. Cogent Economics \& Finance, 7(1), 1664192.

Odunga, R. M. (2016). Specific performance indicators, market share and operating efficiency for commercial banks in Kenya. International Journal of Finance and Accounting, 5(3), 135145.

Olarewaju, O. M., \& Obalade, A. A. (2015). Evaluation of the determinants of operational efficiency in Nigerian deposit money banks. International Journal of Economics, Commerce and Management, 3(2), 1-13.

Olarewaju, O. M., \& Obalade, A. A. (2015). Evaluation of the determinants of operational efficiency in Nigerian deposit money banks. International Journal of Economics, Commerce and Management, 3(2), 1-13.

Raza, H., Saeed, A., Scholar, M. P., \& Hena, S. Determinants of Profitability in Banking Sector: An Evidence from Pakistan.

Sharifi, S., Haldar, A., \& Rao, S. N. (2016). Relationship between operational risk management, size, and ownership of Indian banks. Managerial Finance.

Sharifi, S., Haldar, A., \& Rao, S. N. (2016). Relationship between operational risk management, size, and ownership of Indian banks. Managerial Finance.

Shyu, J., Lin, J. C., \& Wu, C. K. (2014). Determinants of operational efficiency in Asian banking: A two-stage banking model analysis. Asian Journal of Finance and Accounting, 6(2).

Singh, A., \& Sharma, A. K. (2016). An empirical analysis of macroeconomic and bank- specific factors affecting liquidity of Indian banks. Future Business Journal, 2(1), 40-53.

Tarus, D. K., Chekol, Y. B., \& Mutwol, M. (2012). Determinants of net interest margins of commercial banks in Kenya: A panel study. Procedia Economics and Finance, 2, 199-208.

Tarus, D. K., Chekol, Y. B., \& Mutwol, M. (2012). Determinants of net interest margins of commercial banks in Kenya: A panel study. Procedia Economics and Finance, 2, 199-208. 